\title{
INOVASI STRATEGI PEMBELAJARAN PAI DALAM MENINGKATKAN MUTU PENDIDIKAN PAI
}

\author{
Noer Rohmah ${ }^{1}$
}

\begin{abstract}
Islamic education has important role in the human life that based on Five Basic of the State, because religion is motivation of life and the important tool of development and self-control. Therefore, religion should be known, understood, and practiced by humans in order to be fully human in life. Nowadays, learning of Islamic Education in the school is more focused on formal and memorization (verbal) and theoretical things, not focused on the purpose so forget about the ability to control themselves and how to build faith. Because of it, teachers need to do various innovation in the process of implementation strategy of Islamic Education in the school, in order to improve quality of Islamic Religion that signed by various change both of cognitive, affective, and psychomotor.
\end{abstract}

Keywords: Innovation of Learning Strategy of Islamic Education, Quality of Islamic Education.

\section{A. Pendahuluan}

Pendidikan merupakan salah satu aspek yang sangat penting untuk membentuk generasi yang siap mengganti tongkat estafet generasi tua dalam rangka membangun masa depan. Karena itu pendidikan berperan mensosialisasikan kemampuan baru kepada mereka agar mampu mengantisipasi tuntutan masyarakat yang dinamik (Muhaimin, 1991 : 9).

Dalam masyarakat yang dinamis pendidikan memegang peranan yang sangat menentukan eksistensi dan perkembangan masyarakat. Oleh karena itu Islam sebagai agama Rahmatan Lil 'Alamin merupakan konsekuensi logis bagi umatnya untuk menyiapkan generasi penerus yang berkualitas, baik moral maupun intelektual serta berketerampilan dan bertanggung jawab. Salah satu upaya untuk menyiapkan genearasi penerus tersebut adalah melalui lembaga pendidikan sekolah.

Secara umum pendidikan agama Islam di sekolah bertujuan untuk menumbuhkan dan meningkatkan keimanan melalui pemberian dan

1 Dosen Sekolah Tinggi Ilmu Tarbiyah (STIT) Ibnu Sina Malang, Jl. Sultan Agung 76 Kepanjen Malang. 
pemupukan pengetahuan, penghayatan, pengamalan serta pengalaman peserta didik tentang agama Islam sehingga menjadi manusia muslim yang terus berkembang dalam hal keimanan, ketakwaannya, berbangsa dan bernegara, serta untuk dapat melanjutkan pada jenjang pendidikan yang lebih tinggi (Kurikulum PAI: 2004), ( Majid, 2004 : 135).

Usaha pembelajaran pendidikan agama Islam di sekolah diharapkan agar mampu membentuk kesalehan pribadi dan sekaligus kesalehan sosial sehingga pendidikan agama diharapkan jangan sampai: (1) menumbuhkan semangat fanatisme; (2) menumbuhkan sikap intoleran di kalangan peserta didik dan masyarakat Indonesia; dan (3) memperlemah kerukunan hidup bergama serta persatuan dan kesatuan nasional (Menteri Agama RI, 1996).

Pada sisi lain usaha peningkatan mutu pendidikan, khususnya pendidikan agama Islam erat kaitannya dalam pembentukan pribadi anak. Dalam pendidikan agama Islam tidak hanya pemberian pengetahuan agama, tetapi juga membentuk anak didik agar mereka hidup sesuai dengan ajaran Islam atau membimbing jasmani rohani berdasarkan hukum-hukum Islam menuju kepada terbentuknya kepribadian utama menurut ukuran-ukuran Islam. Sedangkan yang dimaksud kepribadian utama adalah kepribadian muslim, yaitu kepribadian yang memiliki nilai-nilai agama Islam, memilih dan memutuskan serta berbuat berdasarkan nilai-nilai Islam dan bertanggung jawab sesuai nilai-nilai Islam (Marimba, 1990 :23).

Dalam ralitas yang ada saat ini ternyata mutu Pendidikan Agama Islam masih jauh dari harapan dalam arti tujuan Pendidikan Agama Islam yang sesungguhnya belum tercapai secara maksimal . Pendidikan Agama Islam yang ada di sekolah-sekolah seakan telah berubah menjadi pengetahuan Agama Islam saja, bukan hanya di sekolah-sekolah umum tapi hal ini juga dialami oleh peserta didik yang ada di sekolah-sekolah agama. Pendidikan Agama tidak dijadikan sebagai sistem nilai dalam kehidupan sehari-hari. Hal ini dibuktikan dengan semakin banyaknya peserta didik yang telah menempuh Pendidikan Agama Islam tapi dalam perilaku sehari-hari mereka banyak yang menyimpang dari tuntutan agama itu sendiri.

Salah satu faktor yang menjadi pemicu terhambatnya tujuan Pendidikan Agama Islam di sekolah adalah proses pembelajaran Pendidikan Agama Islam baik dari segi strategi pembelajaran yang 
dilakukan guru kurang mengena pada sasaran disamping itu sistem evaluasi yang digunakan belum totalitas, sehingga perubahan yang sudah dicapai oleh guru hanya dalam dataran kognitif saja, belum mencapai aspek afektif dan psikomotor secara sempurna.

Bertolak dari uraian di atas, usaha untuk mencapai efesiensi dan efektifitas kerja dalam rangka mencapai tujuan Pendidikan Agama Islam, perlu adanya inovasi strategi pembelajaran yang tepat untuk meningkatkan mutu pendidikan khususnya Pendidikan Agama Islam. Oleh karena itu inovasi dalam pendidikan sangat perlu untuk diterapkan.

Yang dimaksud inovasi (pembaharuan) dalam kajian ini bukan berarti bahwa sistem pendidikan yang ada perlu diperbaharui atau sama sekali tidak dapat dipergunakan lagi, akan tetapi merubah dan memperbaiki yang rasa kurang efektif menurut ukuran zaman. Sebab kalau tidak ada perbaharuan dalam sistem pendidikan, maka pendidikan akan tertinggal oleh roda zaman (Martin, 1981 : 20-21).

Dalam hal ini keberhasilan seorang guru dalam menyampaikan suatu materi pelajaran, banyak dipengaruhi oleh beberapa faktor, satu di antaranya ialah pemilihan strategi pembelajaran yang tepat. Ketepatan strategi yang digunakan, baik berupa metode, pemanfaatan sarana dan lain sebagainya, akan membawa efektivitas dan efesiensi kerja.

\section{B. Konsep Dasar Inovasi Pembelajaran PAI}

\section{Konsep Inovasi}

Inovasi berarti pembaharuan. Kata innovation dari bahasa inggris sering diterjemahkan segala hal yang baru atau pembaharuan. Kemudian dalam bahasa Indonesia menjadi inovasi. Inovasi terkadang dipaskai untuk menyatakan penemuan, tetapi inovasi juga diartikan pengembangan dari sesuatu yang belum berkembang, hal ini diperkuat oleh M. Saleh Muntasir yang mengatakan bahwa pengertian dari inovasi itu sendiri adalah suatu perubahan yang khusus, baru, dan dipikirkan masak-masak, yang diperkirakan pembaharuan itu akan lebih berhasil dalam menyelesaikan suatu sistem, suatu inovasi merupakan hal yang dikehendaki dan direncanakan, bukan suatu yang tiba-tiba saja ( Muntasir, 1985 : 146). 
Sedangkan kata penemuan sering diterjemah dalam bahasa inggris Discovery, dan invention. Kata innovation, discovery, dan invention mengandung arti ditemukannya sesuatu yang baru, baik barang itu sendiri sudah ada lama kemudian baru diketahui atau memang benarbenar baru dalam arti sebelumnya tidak ada. Dalam kamus besar bahasa Indonesia (1996), inovasi ialah pemasukan atau pengenalan hal-hal baru, pembaharuan, penemuan baru dari yang sudah ada atau yang sudah dikenal sebelumnya (gagasan, metode atau alat).

Pada sisi yang lain inovasi merupakan suatu ide, hal-hal yang praktis, metode, cara, barang-barang buatan manusia, yang diamati dirasakan sebagai suatu yang baru bagi seseorang atau kelompok orang (masyarakat). Inovasi sebagai perubahan disengaja, baru, khusus untuk mencapai tujuan-tujuan sistem. Hal yang baru itu dapat berupa hasil invention atau discovery yang digunakan untuk mencapai tujuan tertentu dan diamati sebagai sesuatu yang baru bagi seseorang atau kelompok masyarakat, jadi perubahan ini direncanakan dan dikehendaki.

Dari definisi inovasi di atas, menurut para ahli tidak ada perbedaan yang mendasar tentang pengertian inovasi anatara satu dengan yang lainnya. Oleh karena itu dapat diambil benang merah bahwa inovasi adalah suatu ide, hal-hal yang praktis, metode, cara, barang-barang buatan manusia, yang diamati atau dirasakan sebagai suatu yang baru bagi seseorang atau kelompok orang (masyarakat). Hal yang baru itu dapat berupa hasil invensi atau discoveri yang digunakan untuk mencapai tujuan tertentu dan diamati sebagai sesuatu yang baru bagi seseorang atau kelompok masyarakat. Jadi inovasi adalah bagian dari perubahan sosial.

Selanjutnya, kata inovasi identik dengan modernisasi. Inovasi dan modernisasi adalah sama-sama perubahan sosial, perbedaannya hanya pada penekanan ciri dari perubahan. Inovasi menekankan pada ciri adanya suatu yang diamati sebagai suatu yang baru bagi individu atau masyarakat. Sedangkan modernisasi menekankan pada adanya proses perubahan dari tradisional ke modern, atau dari belum maju ke yang sudah maju.

Jadi dapat disimpulkan bahwa diterimanya suatu inovasi adalah sebagai tanda adanya modernisasi. Menurut peneliti bahwa inovasi yang dimaksud adalah "pembaharuan" dalam pembelajaran. Inovasi merupakan hal baru bagi lembaga pendidikan yang baru menerima 
dan tidak baru lagi bagi lembaga pendidikan yang telah merancang atau memulainya lebih dulu.

\section{Dasar dan Tujuan Inovasi Dalam Pembelajaran PAI}

Yang menjadi dasar dan tujuan inovasi dalam pembelajaran PAI adalah mengacu pada inovasi pendidikan, karena pembelajaran merupakan suatu komponen dari pendidikan itu sendiri. Salah satu permasalahan serius yang dihadapi dunia pendidikan sekarang ini adalah rendahnya kualitas pembelajaran, termasuk pembelajaran PAI. Proses pembelajaran pendidikan agama yang terjadi kerap kali baru bersifat seadanya, rutinitas, formalitas, kering dan kurang makna. Kualitas pembelajaran semacam itu akan menghasilkan mutu pendidikan agama yang rendah pula.

Adapun tujuan pembaharuan pendidikan adalah meningkatkan efesiensi, relevansi kualitas dan efektifitas, sarana serta jumlah peserta didik yang sebanyak-banyaknya, dengan hasil pendidikan yang sebesarbesarnya (menurut kriteria kebutuhan peserta didik, mastarakat dan pembangunan) dengan menggunakan tenaga, sumber, uang, alat, dan waktu yang sekecil-kecilnya.

Maksud dari pembaharuan di sini bukan berarti bahwa sistem pendidikan, yang perlu diperbaharui adalah sama sekali tidak dapat di pergunakan lagi, akan tetapi hanya merubah dan memperbaiki yang dirasa kurang efektif menurut ukuran zaman. Sebab kalau tidak ada pembaharuan dalam sistem pendidikan akan tertinggal oleh zaman.

Padahal perubahan dan perkembangan ilmu pengetahuan dan teknologi yang cepat ini harus dijawab oleh lembaga sekolah. Selanjutnya B. Suparna menjelaskan, disamping pembaharuan itu untuk memenuhi kebutuhan yang dihadapi dan tantangan terhadap masalah-masalah pendidikan serta tuntutan zaman, perubahan pendidikan juga merupakan usaha aktif untuk mempersiapkan diri di hari esok yang lebih baik dan memberi harapan yang sesuai dengan cita-cita yang didambakan ( Martin, $1981: 21$ ).

Mengacu pada pembaharuan pendidikan di atas, maka upaya tujuan dari inovasi pembelajaran PAI di sini adalah mengembangkan perencanaan pembelajaran pendidikan agama yaitu diantaranya; memilih dan menetapkan metode pembelajaran pendidikan agama yang optimal 
untuk mencapai hasil pembelajaran yang maksimal ( Muhaimin :195). Karena itu, tekanan utama dalam perencanaan pembelajaran adalah pada pemilihan, penetapan, dan pengembangan variabel metode pembelajaran pendidikan agama. Pemilihan metode pembelajarn pendidikan agama harus didasarkan pada analisis kondisi pembelajaran pendidikan agama yang ada, yang nantinya hasil analisis akan menunjukkan kondisi pembelajaran pendidikan agama yang diharapkan. Setelah menetapkan dan mengembangkan metode pembelajaran pendidikan agama dalam kegiatan perencanaan pembelajaran akan diperoleh informasi yang lengkap mengenai kondisi riil yang ada dan hasil pembelajaran pendidikan agama yang diharapkan.

\section{Inovasi Strategi Pembelajaran Pendidikan Agama Islam}

Strategi adalah suatu upaya dan usaha dalam mewujudkan suatu harapan dan tujuan. Strategi yang dimaksudkan di sini strategi yang spesifikasinya pada pendidikan atau pembelajaran pendidikan. Secara umum pengertian strategi yang dimaksud adalah sebagai cara guru dalam menyajikan isi pelajaran dalam lingkup pendidikan. Menurut Syaiful Bahri secara umum strategi mempunyai pengertian suatu garisgaris besar haluan untuk bertindak dalam usaha mencapai sasaran yang telah ditentukan. Pengertian tersebut jika dihubungkan dengan pembelajaran, strategi dapat diartikan sebagai pola-pola umum kegiatan guru dan anak didik dalam perwujudan kegiatan pembelajaran untuk mencapai tujuan yang telah digariskan ( Saiful, 2002 :5). Strategi juga diartikan sebagai pendekatan guru terhadap penggunaan informasi, pemilihan sumber-sumber dan merumuskan peranan para anak didik. Strategi meliputi praktek-praktek yang spesifik yang digunakan untuk mencapai tujuan mengajar ( Sulaiman, 1988 :180).

Sedangkan pembelajaran adalah upaya guru untuk mempersiapkan anak didik untuk menjadi warga masyarakat yang baik. Menurut Zainal Aqib, pembelajaran adalah pertama; Pembelajaran merupakan suatu upaya guru mengorganisasi lingkungan untuk menciptakan kondisi belajar bagi anak didik, kedua; pembelajaran adalah suatu proses membantu siswa (anak didik) menghadapi kehidupan masyarakat sehari-hari ( Aqib, 2002 :41). Jelasnya strategi pembelajaran berkenaan dengan pemilihan kegiatan belajar mengajar yang paling efektif dan efisien dalam memberikan pengalaman belajar yang diperlukan guna 
mencapai tujuan pembelajaran yang telah ditetapkan.

Strategi pembelajaran adalah suatu kegiatan pembelajaran yang harus dikerjakan guru dan siswa agar tujuan pembelajaran dapat dicapai secara efektif dan efisien. Di lain pihak Dick \& Carey menyatakan bahwa "Strategi pembelajaran adalah suatu set materi dan prosedur pembelajaran yang digunakan secara bersama-sama untuk menimbulkan hasil belajar pada siswa. Dari uraian di atas tergambar bahwa ada empat masalah pokok yang sangat penting yang dapat dan harus dijadikan pedoman dalam pelaksanaan kegiatan belajar mengajar supaya sesuai dengan yang diharapkan" ( Walter, $1994: 3$ )

Pertama, spesifikasi dan kualifikasi perubahan tingkah laku yang diinginkan sebagai hasil belajar mengajar yang dilakukan. Dengan kata lain apa yang harus dijadikan sasaran dari kegiatan belajar mengajar tersebut. Sasaran ini harus dirumuskan secara jelas dan konkrit sehingga mudah dipahami oleh peserta didik. Perubahan perilaku dan kepribadian yang kita inginkan terjadi setelah siswa mengikuti suatu kegiatan belajar mengajar itu harus jelas, misalnya dari tidak tahu tentang Sejarah Islam berubah menjadi tahu Sejarah Islam minimal berubah dari semula.

Kedua, memilih cara pendekatan belajar mengajar yang dianggap paling tepat dan efektif untuk mencapai sasaran. Bagaimana cara kita memandang suatu persoalan, konsep, pengertian dan teori apa yang kita gunakan dalam memecahkan suatu kasus akan mempengaruhi hasilnya. Suatu masalah yang dipelajari oleh dua orang dengan pendekatan berbeda, akan menghasilkan kesimpulan-kesimpulan yang tidak sama. Norma-norma sosial seperti baik, benar, adil, dan sebagainya akan melahirkan kesimpulan yang berbeda bahkan mungkin bertentangan kalau dalam cara pendekatannya menggunakan berbagai disiplin ilmu. Juga akan tidak sama apa yang dikatakan baik, benar atau adil kalau kita menggunakan pendekatan agama karena pengertian, konsep, dan teori agama mengenai baik, benar atau adil itu jelas berbeda dengan konsep yang umum.

Ketiga, memilih dan menetapkan prosedur, metode, dan teknik belajar mengajar yang dianggap paling tepat dan efektif. Metode atau teknik penyajian untuk memotivasi siswa supaya murid-murid terdorong dan mampu berfikir bebas dan cukup keberanian untuk mengemukakan pendapatnya sendiri. Perlu dipahami bahwa suatu 
metode mungkin hanya cocok dipakai untuk mencapai tujuan tertentu. Jadi dengan sasaran yang berbeda hendaknya tidak menggunakan teknik penyajian yang sama.

Keempat, menetapkan norma-norma atau kriteria keberhasilan sehingga guru mempunyai pegangan yang dapat dijadikan ukuran untuk menilai sampai sejauh mana keberhasilan tugas-tugas yang telah dilakukannya. Suatu program baru bisa diketahui keberhasilannya setelah dilakukan evaluasi. Sistem penilaian dalam kegiatan belajar mengajar merupakan salah satu strategi yang tidak bisa dipisahkan dengan strategi dasar lain. Apa yang harus dinilai dan bagaimana penilaian itu harus dilakukan termasuk kemampuan yang harus dimiliki oleh guru. Seorang siswa dapat dikategorikan sebagai murid yang berhasil bisa dilihat dari berbagai segi. Bisa dilihat dari segi kerajinannya mengikuti tatap muka dengan guru, perilaku sehari-hari di sekolah, hasil ulangan, hubungan sosial dan sebagainya atau dilihat dan berbagai aspek.

Kelima dasar strategi tersebut merupakan satu kesatuan yang utuh antara dasar yang satu dengan dasar yang lain saling menopang dan tidak bisa dipisahkan. Serta ada beberapa prinsip-prinsip yang mesti dilakukan oleh Guru dalam memilih strategi pembelajaran secara tepat dan akurat, pertimbangan tersebut mesti berdasarkan pada penetapan :

a. Tujuan Pembelajaran

b. Aktivitas dan Pengetahuan Awal Siswa

c. Integritas Bidang Studi / Pokok Bahasan

d. Alokasi Waktu dan Sarana Penunjang

e. Jumlah Siswa

f. Pengalaman dan Kewibawaan Pengajar.(Dirjen tenaga kependidikan, $2008: 45)$.

Untuk selanjutnya kedudukan Strategi Pembelajaran Pendidikan Agama Islam dalam Proses Belajar Mengajar, menurut Gagne, Briggs dan Wager adalah berada dalam lingkup desain/rancangan pengajaran yang menduduki langkah keenam (Kusrini , 1995: 8 ). Ada 9 langkah dalam penyusunan desain pengajaran, masing-masing adalah : (1) tujuan pengajaran, (2) analisis pengajaran, (3) penetapan kemampuan dan karakteristik siswa, (4) tujuan kinerja/ penampilan (5) butir tes, 
(6) strategi pengajaran, (7) bahan pengajaran, (8) tes formatif dan (9) tes sumatif.

Strategi Pendidikan Agama Islam merupakan rencana yang disusun oleh guru dalam membimbing, membantu dan mengarahkan siswa yang sedang belajar untuk mencapai Tujuan Instruksional Khusus ( TIK ). Dalam rencana ini guru harus menjelaskan rincian kegiatan siswa dan kegiatan guru dalam KBM yang terikat oleh acuan ke TIK. Jika salah satu butir itu mengatakan, "Siswa dapat menyebutkan 6 contoh dari hal-hal yang wajib diimani “, maka KBM itu harus jelas menggambarkan tindakan guru dan siswa dalam pembahasan keimanan, jika pembahasan oleh siswa itu ternyata menyimpang dari konsep akhlak yang berakibat menyimpang dari TIK maka guru harus bertindak dengan cara meluruskan isi pembahasan ke arah pembahasan keimanan.

Rencana mengajar dapat disusun secara tertulis oleh guru, dapat berupa satuan pelajaran atau berupa penggunaan media sebagai pengganti guru sesaat. Dan bahkan dapat berupa modul, buku ajar/ buku paket yang dipelajari oleh siswa secara individual. Jadi dalam pelajaran klasikal atau modul, sebanarnya peran guru tidak berkurang, tetapi melakukan peran berbeda dengan maksud tetap membantu siswa untuk belajar. Dengan kata lain strategi belajar mengajar pada dasarnya mengarahkan perhatian siswa kepada pelajaran yang sedang diikuti, menjelaskan tentang TIK yang akan dicapai, menyajikan bahan pelajaran yang seusai dengan kebutuhan dan minat anak didik sehingga termotivasi untuk belajar dan mengetahui hasilnya yang dicapai dari kegiatan belajar mengajar itu.

Untuk selanjutnya inovasi (pembaharauan) dalam strategi pembelajaran pendidikan agama Islam, sebenarnya sejak kurikulum 1975 diberlakukan, dimana seorang guru dituntut untuk menggunakan berbagai metode di dalam menyampaikan materi pelajaran. Lebih lagi dengan penambahan kurikulum 1994 yang diarahkan pada Cara Belajar Siswa Aktif (CBSA).

Untuk memahami hal tersebut maka strategi pembelajaran dapat dibedakan menjadi 3 jenis, yaitu: (1) strategi pengorganisasian isi pembelajaran, (2) strategi penyampaian isi pembelajaran, dan (3) strategi pengelolaan pembelajaran, ketiganya dapt dibagankan sebagaimana tercantum pada gambar di bawah ini: 


\section{Startegi Pembelajaran}

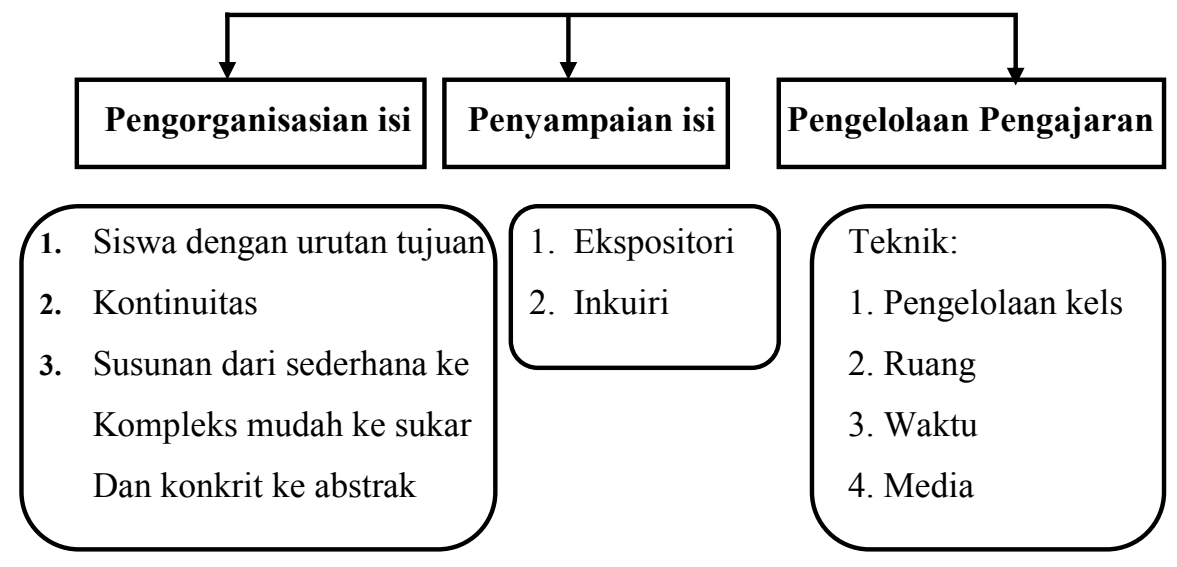

Gambar 2.1 Strategi pembelajaran

1. Dalam hal pengorganisasian bahan guru harus memperhatikan:

a. Bahan pembelajaran harus sesuai dengan urutan tujuan

b. Urutan bahan memperhatikan kesinambungan, artinya antara bahan yang satu menjadi dasar bahan yang lain

c. Bahan disusun dari yang sederhana menuju yang kompleks, dari yang mudah menuju yang sulit, dari yang konkrit menuju yang abstrak.

d. Sifat bahan yang factual dan ada yang konseptual.

Contoh pengorganisasian bahan pembelajaran bahan agama Islam dengan pokok bahasan "Rukun Iman" yang dapat disusun sebagai berikut: 


\section{Bagan Pengorganisasian Bahan Pembelajaran}

Pendidikan Agama Islam

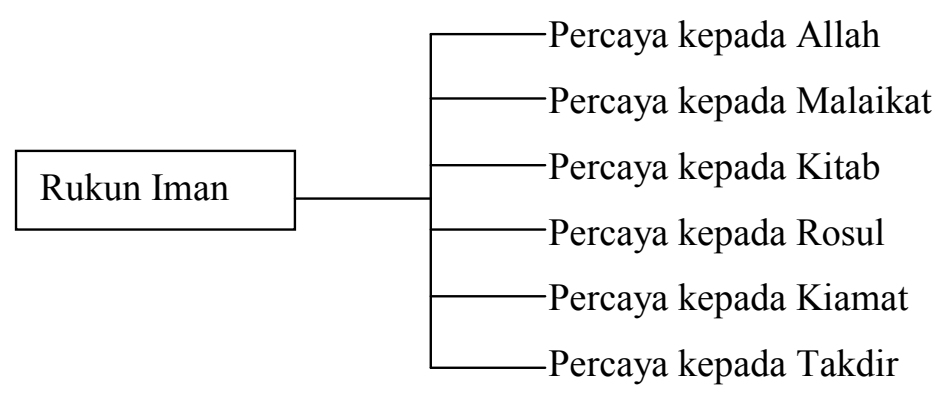

Gambar 2.2 Bagan Pengorganisasian Bahan Pembelajaran PAI

2. Dalam penyampaian bahan pelajaran: guru perlu memperhatikan bahwa pemahaman belajar masyarakat ini bertujuan menyampaikan pesan-pesan yang dapat berupa pengetahuan, wawasan, ketrampilan dan perasaan. Strategi penyampaian bahan pembelajaran tersebut dapat dibedakan menjadi dua bagian, yaitu:

a. Strategi Ekspositori (Expository Strategy) yakni penyampaian bahan secara tuntas oleh guru sebelum disampaikan kepada anak didik. Dalam hal ini anak didik hanya tinggal mendengarkan, mencatat, menghafalkan bahan yang disampaikan oleh guru. Contoh pokok bahasan Rukun Iman setelah disusun oleh guru secara lengkap antara lain meliputi pelatihan pengertian Rukun Iman kepada Allah, Sifat-sifat Allah dan keyakinan akan adanya Allah.

b. Startegi Inkuiri (Inquiry Strategy ) yakni penyampaian bahan pengajaran yang mebgharuskan pengelolaan bahan oleh siswa. Strategi ini bertitik tolak pada pandangan bahwa siswa sebagai subyek, dan obyek dalam belajar mempunyai kemampuan dasar untuk berkembang secara optimal sesuai dengan kemampuan yang dimilikinya. Inquri meletakkan dasar dan pengembangan cara berfikir sehingga berkembang pula kreatifitas siswa dalam menghadapi dan memecahkan masalah. 
Berdasarkan GBPP maka pengajaran Agama Islam menggunakan beberapa pendekatan sesuai dengan karakteristiknya sebagai pendekatan, yaitu: (1) pendekatan pengalaman, (2) Pendekatan pembiasaan, (3) Pendekatan emosional, (4) Pendekatan rasional, dan (5) Pendekatan fungsional. Jenis-jenis pendekatan ini mempunyai fungsi yang berbeda namun mempunyai kesinambungan dalam rangka mencapai tujuan untuk meyakini dan mengamlkan ajaran-ajaran tersebut. Dalam hal ini guru harus membiasakan anak didik untuk berperilaku seharihari sesuai dengan ajaran Agama Islam. Dari keadaan ini anak didik diharapkan memiliki pengalaman tentang nilai-nilai Agama Islam yang dapat menggugah perasaan. (ranah afektif) untuk meyakini ajaran Agama Islam sebagai kebenaran yang mutlak serta bermanfaat sebagai pedoman hidupnya.

Sehubungan dengan hal tersebut maka diperlukan pengelolaan pembelajaran oleh guru dalam menciptakan dan mengkondisikan situasi belajar mengajar sebagai siswa melakukan kegiatan belajar mengajar secara optimal. Usaha tersebut dilakukan guru pada saat berlangsungnya proses belajar mengajar. Untuk memenuhi hal ini maka guru harus menggunakan prinsip-prinsip mengajar antara lain: motivasi pengelompokkan siswa, alokasi waktu, ruang dan memilih media pembelajaran yang tepat. Prinsip-prinsip tersebut perlu dilaksanakan agar siswa melakukan kegiatan belajar dengan suasana yang meyenangkan.

Benarlah sejak awal seperti yang dinyatakan oleh Gilstrap dan Martin (1975:54) bahwa guru berperan penting dalam merencanakan pengajaran sebagai pedoman menampilkan ketrampilan mengajar dan perilakunya di kelas. Penciptaan suasana batin yang demikian itu member peluang kepada siswa untuk meningkatkan kemauan menerapkan ajaran agama. Dengan demikian dapatlah diharapkan terbentuknya kata hati/ suara hati yang merupakan modal dasar bagi siswa dalam memilih, mempertimbangkan serta memutuskan segala perilaku hidup sehariharinya. Hal ini diperkuat oleh Good dan Brophy (1987:363) bahwa kegiatan belajar memerlukan peran guru secara langsung sementara siswa melaksanakan tugas individual yang antara lain menetapkan tujuan yang dikehendaki dan cara belajar mandiri.

Dari beberapa uraian di atas dapat dipahami bahwa strategi pendidikan dalam konteks pembelajaran adalah langkah-langkah nyata 
yang ditempuh oleh guru dan anak didik secara sistemik dan sistematik untuk mencapai hasil yang optimal sesuai dengan harapan. Adapun langkah-langkah itu meliputi:

a. Merumuskan spesifikasi dan kualifikasi perubahan tingkah laku yang diinginkan sebagai hasil belajar.

b. Memilih cara pendekatan belajar mengajar yang dianggap penting tepat dan efektif untuk mencapai sasaran, pendekatan disini berarti cara memandang persoalan, konsep pengertian/jenis teori yang digunakan untuk memecahkan suatu kasus yang dapat mempengaruhi hasilnya.

c. Menetapkn prosedur, metode dan teknik belajar mengajar yang dianggap paling tepat dan efektif. Pengertian metode disini adalah cara yang digunakan untuk mengadakan interaksi antara guru dan siswa dalam menyampaikan pesan-pesan. Sedangkan teknik adalah cara yang ditempuh dengan menggunakan sarana pengajaran untuk mengarahkan/memotivasi kegiatan siswa yang benar dalam mencapai tujuan.

d. Menetapkan norma-norma/kriteria keberhasilan yang dapat dijadikan ukuran untuk menilai pencapaian tujuan yang telah ditetapkan.

Keempat langkah tersebut harus dijadikan pedoman bagi pelaksanaan kegiatan belajar mengajar agar tercapai hasil yang sesuai dengan yang diharapkan. Kemudian untuk meningkatkan kualitas pendidikan, maka Pemerintah senantiasa berupaya, baik secara konvensional maupun inovatif. Pendidikan akan selalu mengalami pembaharuan dalam meningkatkan mutu pendidikan itu sendiri melalui kurikulum sebagai upaya yang sudah dilakukan oleh pemerintah. Dengan pembaharuan tesebut, maka strategi pembelajaranpun senantiasa akan mengalami perubahan (pembaharuan).

Adapun perbedaan pendidikan konvensional dan inovatif akan dijelaskan pada tabel dibawah ini: 
Noer Rohmah - Inovasi Strategi Pembelajaran PAI dalam ...

\begin{tabular}{|c|c|}
\hline INOVATIF & KONVENSIONAL \\
\hline $\begin{array}{l}\text { Siswa secara aktif terlibat dalam } \\
\text { proses pembelajaran. }\end{array}$ & $\begin{array}{l}\text { 1. Siswa adalah penerima informasi } \\
\text { secara pasif. }\end{array}$ \\
\hline $\begin{array}{l}\text { Siswa belajar dari teman melalui } \\
\text { kerja kelompok, diskusi, saling } \\
\text { mengoreksi. }\end{array}$ & 2. Siswa belajar secara individual. \\
\hline $\begin{array}{l}\text { Pembelajaran dikaitkan dengan } \\
\text { kehidupan nyata dan atau } \\
\text { masalah yang disimulasikan. }\end{array}$ & $\begin{array}{ll}\text { 3. } & \text { Pembelajaran sangat abstrak } \\
\text { dan teoritis. }\end{array}$ \\
\hline $\begin{array}{l}\text { 4. Perilaku dibangun atas kesadaran } \\
\text { diri. }\end{array}$ & 4. $\begin{array}{l}\text { Perilaku dibangun atas } \\
\text { kebiasaan. }\end{array}$ \\
\hline $\begin{array}{l}\text { Keterampilan dikembangkan atas } \\
\text { dasar pemahaman. }\end{array}$ & $\begin{array}{l}\text { 5. Keterampilan dikembangkan atas } \\
\text { dasar latihan. }\end{array}$ \\
\hline $\begin{array}{l}\text { Hadiah untuk perilaku baik adalah } \\
\text { kepuasan. }\end{array}$ & \begin{tabular}{|ll} 
6. & Hadiah untuk perilaku baik adalah \\
pujian atau nilai (angka) rapor.
\end{tabular} \\
\hline $\begin{array}{l}\text { 7. Seseorang tidak melakukan yang } \\
\text { jelek karena dia sadar hal itu } \\
\text { keliru dan merugikan. }\end{array}$ & 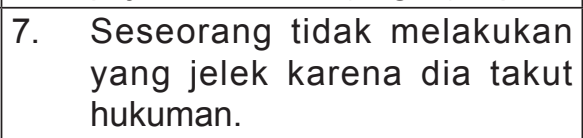 \\
\hline 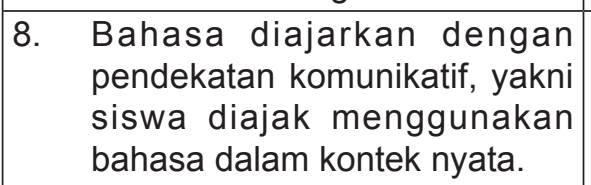 & $\begin{array}{ll}\text { 8. } & \text { Bahasa diajarkan dengan } \\
\text { pendekatan structural: rumus } \\
\text { diterangkan sampai paham, } \\
\text { kemudian dilatihkan (driill). }\end{array}$ \\
\hline 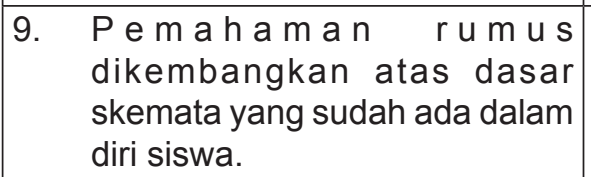 & $\begin{array}{l}\text { 9. Rumus itu ada di luar siswa, } \\
\text { yang harus diterengkan, diterima, } \\
\text { dihafalkan, dan dilatihkan. }\end{array}$ \\
\hline $\begin{array}{l}\text { 10. Pemahaman rumus itu relatif } \\
\text { berbeda antara siswa yang satu } \\
\text { dengan lainnya, sesuai dengan } \\
\text { skemata siswa (ongoing process } \\
\text { of development). }\end{array}$ & $\begin{array}{l}\text { 10. Rumus adalah kebenaran absolut } \\
\text { (sama untuk semua orang). } \\
\text { Hanya ada dua kemungkinan, } \\
\text { yaitu pemahaman rumus yang } \\
\text { salah atau pemahaman rumus } \\
\text { yang benar. }\end{array}$ \\
\hline $\begin{array}{l}\text { 11. Siswa menggunakan kemampuan } \\
\text { berpikir kritis, terlibat penuh dalam } \\
\text { mengupayakan terjadinya proses } \\
\text { pembelajaran yang efektif, ikut } \\
\text { beranggung jawab atas terjadinya } \\
\text { proses pembelajaran yang } \\
\text { efektif, dan membawa skemata } \\
\text { masing-masing ke dalam proses } \\
\text { pembelajaran. }\end{array}$ & $\begin{array}{l}\text { 11. Siswa secara pasif menerima } \\
\text { rumus atau kaidah (membaca, } \\
\text { mendengarkan, mencatat, } \\
\text { menghafal), tanpa memberi } \\
\text { kontribusi ide dalam proses } \\
\text { pembelajaran. }\end{array}$ \\
\hline
\end{tabular}




\begin{tabular}{|c|c|c|}
\hline & $\begin{array}{l}\text { Pengetahuan yang dimilikimanusia } \\
\text { yang dikembangkan oleh manusia } \\
\text { itu sendiri. Manusia menciptakan } \\
\text { atau membangun pengetahuan } \\
\text { dengan cara memberi arti dan } \\
\text { memahami pengalamannya. }\end{array}$ & $\begin{array}{l}\text { 12. Pengetahuan ad a la h } \\
\text { penangkapan terhadap } \\
\text { serangkaian fakta, konsep, atau } \\
\text { hukum yang berada di luar diri } \\
\text { manusia. }\end{array}$ \\
\hline 13. & $\begin{array}{l}\text { Karena ilmu pengetahuan itu } \\
\text { dikembangkan (dikonstruksikan) } \\
\text { oleh manusia sendiri, semenara } \\
\text { manusia selalu mengalami } \\
\text { peristiwa baru, maka } \\
\text { pengetahuan itu tidak pernah } \\
\text { stabil, selalu berkembang } \\
\text { (tentative \& incomplete). }\end{array}$ & $\begin{array}{l}\text { Kebenaran bersifat absolut dan } \\
\text { pengetahuan bersifat final. }\end{array}$ \\
\hline 14. & $\begin{array}{l}\text { Siswa diminta bertanggung jawab } \\
\text { memonitor dan mengembangkan } \\
\text { pembelajaran mereka masing- } \\
\text { masing. }\end{array}$ & $\begin{array}{l}\text { 14. Guru adalah penentu jalannya } \\
\text { proses pembelajaran. }\end{array}$ \\
\hline 15. & $\begin{array}{l}\text { Penghargaan terhadap } \\
\text { pengalaman siswa sangat } \\
\text { diutamakan. }\end{array}$ & $\begin{array}{l}\text { 15. Pembelajaran tidak memprhatikan } \\
\text { pengalaman siswa. }\end{array}$ \\
\hline 16. & $\begin{array}{l}\text { Hasil belajar diukur dengan } \\
\text { berbagai cara: proses bekerja, } \\
\text { hasil karya, penampilan, } \\
\text { rekaman, tes, dan lain-lain. }\end{array}$ & $\begin{array}{l}\text { Hasil belajar diukur hanya dengan } \\
\text { tes. }\end{array}$ \\
\hline 17. & $\begin{array}{l}\text { Pembelajaran terjadi di berbgai } \\
\text { tempat, konteks, dan setting. }\end{array}$ & $\begin{array}{l}\text { 17. Pembelajaran hanya terjadi } \\
\text { dalam kelas. }\end{array}$ \\
\hline 18. & $\begin{array}{l}\text { Penyelesaian adalah hukuman } \\
\text { dari perilaku jelek. }\end{array}$ & $\begin{array}{l}\text { 18. Sanksi adalah hukuman dari } \\
\text { perilaku jelek. }\end{array}$ \\
\hline & $\begin{array}{l}\text { Perilaku baik berdasar motivasi } \\
\text { intrinsic. }\end{array}$ & $\begin{array}{l}\text { 19. Perilaku baik berdasar motivasi } \\
\text { ekstrinsik. }\end{array}$ \\
\hline & $\begin{array}{l}\text { Seseorang berperilaku baik } \\
\text { karena dia yakin itulah yang } \\
\text { terbaik dan bermanfaat. }\end{array}$ & $\begin{array}{l}\text { 20. Seseorang berperilaku baik } \\
\text { karena dia terbiasa melakukan } \\
\text { begitu. Kebiasaan in i } \\
\text { dibangun dengan hadiah yang } \\
\text { menyenangkan. }\end{array}$ \\
\hline
\end{tabular}

Dari tabel di atas dapat diambil pengetian bahwa melalui kurikulum yang mengalami pembaharuan, maka strategi pembelajaran yang digunakan oleh guru dalam menyampaikan suatu materi pelajaran juga akan mengalami pembaharuan yang menitik beratkan pada hasil pembelajaran itu sendiri. Dengan demikian inovasi strategi pembelajaran 
Noer Rohmah - Inovasi Strategi Pembelajaran PAI dalam ...

pendidikan agama Islam diartikan sebagai kegiatan guru agama dalam proses belajar mengajar keagamaan yang dapat memberikan kemudahan atau menyediakan fasilitas anak didik menuju tujuan.

\section{B. Peningkatam Mutu Pendidikan}

\section{Pengertian Mutu Pendidikan}

Secara umum, mutu adalah gambaran dan karakteristik menyeluruh dari barang atau jasa yang menunjukkan kemampuannya dalam memuaskan kebutuhan yang yang diharapkan atau yang tersirat. Dalam konteks pendidikan, pengertian mutu mencakup input, proses dan output pendidikan (Sallis, $2008: 35$ ).

Input pendidikan adalah segala sesuatu yang harus tersedia karena dibutuhkan untuk berlangsungnya proses ( usman, 2006 : 132). Sesuatu yang dimaksud berupa sumberdaya dan perangkat lunak serta harapanharapan sebagai pemandu bagi berlangsungnya proses. Input sumberdaya meliputi sumberdaya manusia (kepala sekolah, guru termasuk guru BP, karyawan, siswa ) dan sumberdaya selebihnya ( peralatan, perlengkapan, uang, bahan, dan sebagainya ). Input perangkat lunak seperti struktur organisasi sekolah, peraturan perundang-undangan, deskripsi tugas, rencana, program, dan sebagainya. Input harapan-harapan berupa visi, misi, tujuan dan sasaran -sasaran yang ingin dicapai oleh sekolah. Kesiapan input sangat diperlukan agar proses dapat berlangsung dengan baik. Oleh karena itu, tinggi rendah nya mutu input dapat diukur dari tingkat kesiapan input. Makin tinggi tingkat kesiapan input, makin tinggi pula mutu input tersebut.

Proses Pendidikan merupakan berubahnya sesuatu menjadi sesuatu yang lain. Sesuatu yang berpengaruh terhadap berlangsungnya proses disebut input, sedang sesuatu hasil proses disebut output. Dalam pendiidkan berskala mikro ( tingkat sekolah ), proses yang dimaksud adalah proses pengambilan keputusan, proses pengelolaan kelembagaan, proses pengelolaan program, proses belajar mengajar, dan proses monitoring dan evaluasi, dengan catatan bahwa proses belajar mengajar memiliki tingkat kepentingan tertinggi dibandingkan dengan prosesproses lainnya.

Proses dikatakan bermutu tinggi apabila pengkoordinasian dan penyerasian serta pemaduan input sekolah ( guru, siswa, kurikulum, 
uang, peralatan, dans ebagainya ) dilakukan secara harmonis, sehingga mampu menciptakan situasi pembelajaran yang menyenangkan (Enjoyable Leaning ), mampu mendorong motivasi dan minat belajar, dan benarbenar mampu memberdayakan peserta didik. Kata memberdayakan mengandung arti bahwa peserta didik tidak sekedar menguasai pengetahuan yang diajarkan oleh gurunya, akan tetapi pengetahuan mereka tersebut juga telah menjadi muatan nurani peserta didik, dihayati, diamalkan dalam kehidupan sehari-hari, dan yang lebih penting lagi peserta didik tersebut mampu belajar secara terus menerus ( mampu mengembangkan dirinya ).

Output pendidikan adalah merupakan kinerja sekolah. Kinerja sekolah adalah prestasi sekolah yang dihasilkan dari proses/ perilaku sekolah. Kinerja sekolah dapat diukur dari kualitasnya, efektivitasnya, produktivitasnya, efisiensinya, inovasinya, kualitas kehidupan kerjanya, dan moral kerjanya. Khusus yang berkaitan dengan mutu output sekolah, dapat dijelaskan bahwa output sekolah dikatakan berkualitas/ bermutu tinggi jika prestasi sekolah, khususnya prestasi belajar siswa menunjukkan pencapaian yang tinggi dalam : (1) prestasi akademik, berupa nilai ulangan umum, UAN, karya ilmiah, lomba akademik; dan (2) prestasi non akademik, seperti misalnya IMTAQ, kejujuran, kesopanan, olahraga, kesenian, keterampilan kejuruan, dan kegiatankegiatan ekstrakurikuler lainnya. Mutu sekolah dipengaruhi oleh banyak tahapan kegiatan yang saling berhubungan ( proses ) seperti misalnya perencanaan, pelaksanaan, dan pengawasan.

\section{Prinsip-Prinsip Mutu Pendidikan}

1. Fokus pada pelanggan (peserta didik)

Dalam dunia pendidikan fokus pada pelanggan ini merupakan fokus pada siswa, karena siswa merupakan obyek yang utama dan pertama dalam proses pendidikan, yang ini lebih dititikberatkan pada proses pendidikan dari pada hasil pendidikan, karenanya fokus pada siswa dalam proses belajar mengajar ini merupakan hal yang sangat urgen dalam mencapai mutu.

Pelanggan disini tidak terfokus pada pelanggan internal saja akan tetapi juga pada pelanggan eksternal, yang mana keduanya sangat penting dalam membangun mutu dan kualitas pendidikan kita. Kemudian yang termasuk pelanggan eksternal ini juga orang tua, 
pemerintah, institusi lembaga swasta (LSM), dan lembaga-lembaga lain yang mendukung terwujudnya mutu pendidikan yang unggul.

\section{Perbaikan proses}

Konsep perbaikan terus menerus dibentuk berdasarkan pada premisi suatu seri (urutan) langkah-langkah kegiatan yang berkaitan dengan menghasilkan output seperti produk berupa barang dan jasa. Perhatian secara terus menerus bagi setiap langkah dalam proses kerja sangat penting untuk mengurangi keragaman dari output dan memperbaiki keandalan. Tujuan pertama perbaikan secara terus menerus ialah proses yang handal, sedangkan tujuan perbaikan proses ialah merancang kembali proses tersebut untuk output yang lebih dapat memenuhi kebutuhan pelanggan, agar pelanggan puas.

\section{Keterlibatan total}

Pendekatan ini dimulai dengan kepemimpinan manajemen senior yang aktif dan mencakup usaha yang memanfaatkan bakat semua karyawan dalam suatu organisasi untuk mencapai suatu keunggulan kompetitif (competitive advantage) di pasar yang dimasuki. Guru dan karyawan pada semua tingkatan diberi wewenang/kuasa untuk memperbaiki output melalui kerja sama dalam struktur kerja baru yang luwes (fleksibel) untuk memecahkan persoalan, memperbaiki proses dan memuaskan pelanggan. Pemasok juga dilibatkan dan dari waktu ke waktu menjadi mitra melalui kerja sama dengan para karyawan yang telah diberi wewenang/kuasa yang dapat menguntungkan (Kholis, 2004 : 123-124).

Edward Deming mengembangkan 14 prinsip yang menggambarkan apa yang dibutuhkan sekolah untuk mengembangkan budaya mutu. Hal ini didasarkan pada kegiatan yang dilakukan sekolah menengah kejuruan tehnik regional 3 di Lincoln, maine dan soundwell college di Bristol, Inggris. Kedua sekolah tersebut dapat mencapai sasaran yang sudah digariskan dalam butir-butir tersebut mampu memperbaiki outcome siswa dan administratif. 14 prinsip tersebut adalah sebagai berikut:

a. Meniciptakan konsistensi tujuan, yaitu untuk memperbaiki layanan dan siswa yang dimaksudkan untuk menjadikan sekolah sebagai sekolah yang kompetitif dan berkelas dunia.

b. Mengadopsi filosofi mutu total, setiap orang harus mengikuti prinsipprinsip mutu. 
c. Mengurangi kebutuhan pengajuan, mengurangi kebutuhan pengajuan dan inspeksi yang berbasis produksi massal dilakukan dengan membangun mutu dan layanan pendidikan. Memberikan lingkungan belajar yang menghasilkan kinerja siswa yang bermutu.

d. Menilai bisnis sekolah dengan cara yang baru, nilailah bisnis sekolah dengan meminimalkan biaya total pendidikan.

e. Memperbaiki mutu dan produktivitas serta mengurangi biaya, memperbaiki mutu dan produktivitas sehingga mengurangi biaya, dengan mengembangkan proses "rencanakan/periksa/ubah".

f. Belajar sepanjang hayat, mutu diawali dan diakhiri dengan latihan. Bila anda mengharapkan orang mengubah cara bekerja mereka, anda mesti memberikan mereka perangkat yang diperlukan untuk mengubah proses kerja mereka.

g. Kepemimpinan dalam pendidikan, merupakan tanggung jawab manajemen untuk memberikan arahan. Para manajer dalam pendidikan mesti mengembangkan visi dan misi untuk wilayah. Visi dan misi harus diketahui dan didukung oleh para guru, orang tua dan komunitas.

h. Mengeliminasi rasa takut, ciptakan lingkungan yang akan mendorong orang untuk bebas bicara.

i. Mengeliminasi hambatan keberhasilan, manajemen bertanggung jawab untuk menghilangkan hambatan yang menghalangi orang mencapai keberhasilan dalam menjalankan keberhasilan.

j. Menciptakan budaya mutu, ciptakanlah budaya mutu yang mengembangkan tanggung jawab pada setiap orang.

k. Perbaikan proses, tidak proses yang sempurna, karena itu carilah cara terbaik, proses terbaik, terapkan tanpa pandang bulu.

l. Membantu siswa berhasil, hilangkan rintangan yang merampok hak siswa, guru atau administrator untuk memiliki rasa bangga pada hasil karyanya.

m. Komitmen, manajemen mesti memiliki komitmen terhadap budaya mutu.

n. Tanggung jawab, berikan setiap orang di sekolah untuk bekerja menyelesaikan transformasi mutu ( Arcaro, 2005 :85-89). 
Noer Rohmah - Inovasi Strategi Pembelajaran PAI dalam ...

\section{Ciri-Ciri Mutu Pendidikan}

Era globalisasi merupakan era persaingan mutu. Oleh karena itu lembaga pendidikan mulai dari tingkat dasar sampai tingkat tinggi harus memperhatikan mutu pendidikan. Lembaga pendidikan berperan dalam kegiatan jasa pendidikan maupun pengembangan sumber daya manusia harus memiliki keunggulan-keunggulan yang diprioritaskan dalam lembaga pendidikan tersebut.

Transformasi menuju sekolah bermutu diawali dengan mengadopsi dedikasi bersama terhadap mutu oleh dewan sekolah, administrator, staff, siswa, guru, dan komunitas ( Mulyasa, 2004 :133). Proses diawali dengan mengembangkan visi dan misi mutu untuk wilayah dan setiap sekolah serta departemen dalam wilayah tersebut.

Visi mutu difokuskan pada lima hal, yaitu:

a. Pemenuhan kebutuhan konsumen

Dalam sebuah sekolah yang bermutu, setiap orang menjadi customer dan sebagai pemasok sekaligus. Secara khusus customer sekolah adalah siswa dan keluarganya, merekalah yang akan memetik manfaat dari hasil proses sebuah lembaga pendidikan (sekolah). Sedangkan dalam kajian umum customer sekolah itu ada dua, yaitu customer internal meliputi orang tua, siswa, guru, administrator, staff dan dewan sekolah yang berada dalam sistem pendidikan. Dan customer eksternal yaitu masyarakat, perusahaan, keluarga, militer, dan perguruan tinggi yang berada di luar organisasi namun memanfaatkan output dari proses pendidikan.

b. Keterlibatan total komunitas dalam program

Setiap orang juga harus terlibat dan berpartisipasi dalam rangka menuju kearah transformasi mutu. Mutu bukan hanya tanggung jawab dewan sekolah atau pengawas, akan tetapi merupakan tanggung jawab semua pihak.

c. Pengukuran nilai tambah pendidikan

Pengukuran ini justru yang seringkali gagal dilakukan di sekolah. Secara tradisional ukuran mutu atas sekolah adalah prestasi siswa, dan ukuran dasarnya adalah ujian. Bilamana hasil ujian bertambah baik, maka mutu pendidikan pun membaik. 
d. Memandang pendidikan sebagai suatu sistem

Pendidikan mesti dipandang sebagai suatu sistem, ini merupakan konsep yang amat sulit dipahami oleh para profesional pendidikan. Hanya dengan memandang pendidikan sebagai sebuah sistem maka para professor pendidikan dapat mengeliminasi pemborosan dari pendidikan dan dapat memperbaiki mutu setiap proses pendidikan.

e. Perbaikan berkelanjutan dengan selalu berupaya keras membuat output pendidikan menjadi lebih baik.

Mutu adalah segala sesuatu yang dapat diperbaiki. Menurut filosofi manajemen lama "kalau belum rusak jangan diperbaiki". Mutu didasarkan pada konsep bahwa setiap proses dapat diperbaiki dan tidak ada proses yang sempurna. Menurut filosofi manajemen yang baru "bila tidak rusak perbaikilah, karena bila tidak dilakukan anda maka orang lain yang akan melakukan". Inilah konsep perbaikan berkelanjutan ( Arcaro : 11-14).

\section{Kesimpulan}

Pendidikan Agama Islam mempunyai perananan yang penting dalam kehidupan manusia, sebab salah satu fungsi dari agama adalah membimbing, mengarahkan serta menunjukkan manusia kepada jalan yang benar untuk mencapai kebahagiaan. Oleh karena itu seyogyanya dalam proses pembelajaran pendidikan agama baik yang dilakukan di sekolah maupun dalam keluarga dilakukan dengan berbagai cara / strategi agar mencapai hasil atau mutu yang memuaskan dengan ditandai tercerminnya nilasi-nilai agama dalam kehidupan sehari-hari.

Maka dari itu perlu dilakukan berbagai inovasi strategi pendidikan dalam konteks pembelajaran yakni langkah-langkah nyata yang ditempuh oleh guru dan anak didik secara sistemik dan sistematik untuk mencapai hasil yang optimal sesuai dengan harapan yang meliputi: (a) Merumuskan spesifikasi dan kualifikasi perubahan tingkah laku yang diinginkan sebagai hasil belajar, (b) Memilih cara pendekatan belajar mengajar yang dianggap penting tepat dan efektif untuk mencapai sasaran, (c) Menetapkn prosedur, metode dan teknik belajar mengajar yang dianggap paling tepat dan efektif, (d) Menetapkan norma-norma/ 
kriteria keberhasilan yang dapat dijadikan ukuran untuk menilai pencapaian tujuan yang telah ditetapkan.

Kemudian ada 9 langkah dalam penyusunan desain pengajaran, masing-masing adalah : (1) tujuan pengajaran, (2) analisis pengajaran, (3) penetapan kemampuan dan karakteristik siswa, (4) tujuan kinerja/ penampilan (5) butir tes, (6) strategi pengajaran, (7) bahan pengajaran, (8) tes formatif dan (9) tes sumatif.

Untuk selanjutnya terdapat 14 prinsip yang menggambarkan apa yang dibutuhkan sekolah untuk mengembangkan budaya mutu, antara lain yaitu : (1) Meniciptakan konsistensi tujuan,(2) Mengadopsi filosofi mutu total, (3) Mengurangi kebutuhan pengajuan, (4) Menilai bisnis sekolah dengan cara yang baru,(5) Memperbaiki mutu dan produktivitas serta mengurangi biaya, (6) Belajar sepanjang hayat, (7) Kepemimpinan dalam pendidikan, (8) Mengeliminasi rasa takut, (9) Mengeliminasi hambatan keberhasilan, (10) Menciptakan budaya mutu, (11) Perbaikan proses, (12) Membantu siswa berhasil,(13 ) Komitmen, (14) Tanggung jawab.

\section{DAFTAR PUSTAKA}

Aqib, Zainal ,Profesionalisme Guru Dalam Pembelajaran. Surabaya : Insan Cendikia, 2002

Bahri, Saiful ,Strategi Belajar Mengajar, Jakarta : Rineka Cipta, 2002

Dick Walter \& Carey Lou, The Systematic design of Instruction, New York : Harper Collins Publishers, 1994

Direktorat Jendral Peningkatan Mutu Pendidikan dan Tenaga Kependidikan Departemen Pendidikan Nasional, Strategi Pembelajaran dan Pemilihannya, Jakarta :Dirjen Tenaga Kependidikan, 2008

Jerome S. Arcaro, Pendidikan Berbasis Mutu, Prinsip-Prinsip Dan Tata Langkah Penerapan, Yogyakarta : Pustaka Pelajar, 2005

Kholis, Nur, Kiat Sukses jadi Praktisi Pendidikan. Sleman : Palem, 2004

Majid, Abdul, Pendidikan Agama Islam Berbasis Kompetensi, Bandung : PT. Remaja Rosdakarya, 2004 
Marimba, Ahmad D, Pengantar Filsafat Pendidikan Islam, Bandung: PT. Al-Ma'arif, 1990

Muhaimin, Konsep Pendidikan Islam, Solo : Ramadhan, 1991

Muntasir, M. Saleh, Mencari Evidensi Islam, Jakarta : Rajawali, 1985

Mulyasa, E, Menjadi Kepala Sekolah Profesional, Bandung : PT. Remaja Rosda Karya , 2004

Sardi, Martin, mencari Identitas Pendidikan, Alumni, Bandung, 1981

Sallis, Edward, Total Quality Management In Education. Jogjakarta : IRCISod , 2008

Sulaiman. Teknologi Metodologi Pengajaran, jakarta : Depdikbud. P2LPTK. 1988

Usman, Husaini, Manajemen Teori, Praktik dan Riset Pendidikan. Jakarta : Bumi Aksara , 2006 
